\title{
Activities of degrowth and political change
}

\section{Heikkurinen, Pasi}

$2019-02-20$

Heikkurinen , P , Lozanoska , J \& Tosi , P 2019 , ' Activities of degrowth and political change ' , Journal of Cleaner Production , vol. 211 , pp. 555-565 . https://doi.org/10.1016/j.jclepro.2018.11.119

http://hdl.handle.net/10138/322065

https://doi.org/10.1016/j.jclepro.2018.11.119

cc_by_nc_nd

acceptedVersion

Downloaded from Helda, University of Helsinki institutional repository.

This is an electronic reprint of the original article.

This reprint may differ from the original in pagination and typographic detail.

Please cite the original version. 
ACCEPTED FOR PUBLICATION, PRE-PRINTED VERSION

(C) The Authors

Reference: Heikkurinen, P., Lozanoska, J., Tosi, P. (2018). Activities of degrowth and political change, Journal of Cleaner Production, 1-55, in print.

\title{
Activities of degrowth and political change
}

Pasi Heikkurinen $^{\mathrm{a}, \mathrm{b}}$, Jana Lozanoska ${ }^{\mathrm{c}}$, Pierre Tosi $^{\mathrm{d}}$

${ }^{a}$ University of Helsinki, Department of Economics and Management

${ }^{\mathrm{b}}$ University of Leeds, Sustainability Research Institute

${ }^{c}$ University for Peace, Department of International Law

${ }^{\mathrm{d}}$ Independent Scholar

\begin{abstract}
Hannah Arendt's three-fold conceptualization of human activity offers a useful base for understanding the necessity of degrowth and the kinds of activities required to achieve it. The article argues that the different roles of labour, work, and action should be acknowledged and scrutinized in detail to appreciate the underpinnings of contemporary over-production and overconsumption, as well as to prompt the organization of an alternative society. While following the Arendtian analysis on the origins of meaningful political change, which emphasizes the utmost importance of 'action', the article also underscores the importance of a different conception of 'labour' through physical activity, such as community supported agriculture, and 'work' through social activity such as building off-grid energy systems. The study aligns itself with Arendt's key insight that the origin of most contemporary problems relates to the disappearance of 'action', which for her is political, but also argues that the distinction between 'paid' and 'non-paid' activity has to be carefully considered in the context of degrowth. The article concludes
\end{abstract}


that non-paid activities, particularly in the form of Arendtian 'action', have great potential to contribute to the degrowth movement. Demonetized activities are important for degrowth, as monetary transactions in capitalist societies based on interest and debt tend to contribute to economic growth, which is deemed ecologically unsustainable.

\section{Introduction}

In the claimed new geological epoch of the Anthropocene (Crutzen and Stoermer, 2000; Steffen et al., 2007), problems of growth economies are increasingly acknowledged in both the scholarly literature and in policy discourses. One of the early contributions to this thinking was The Limits to Growth report by Meadows et al. (1972). The study noted the impossibility of having continuous economic and population growth with a finite natural resource base. In their thirty-year update, they authors repeated that augmented anthropogenic pressure meant the Earth is in a dangerous state of overshoot, and presented statistical evidence even stronger than that offered previously to support the claim (Meadows et al., 2004; also Turner, 2008). Importantly for the cause of sustainability, it is now beginning to be commonly accepted that humankind is using the world's natural resources faster than they can renew and emitting waste faster than the biosphere can absorb it. The Intergovernmental Panel on Climate Change (IPCC, 2014) states that the main drivers of global environmental change are economic and population growth. For humanity, these findings signify that a return to living within the biophysical limits of Earth would necessitate degrowth in terms of both the size of the economy and the populace.

Owing to the relatively small reduction potential of the economy in the developing countries, as well as the inequitable distribution of affluence, degrowth is expected to begin in the world's wealthiest economies 
(Georgescu-Roegen, 1975; Daly, 1996; Latouche, [2007] 2009). Degrowth would require reductions in the scale of all practices that contribute to ecological destruction. At the minimum, the economies of the world would have to be downsized to the extent that their resource use and waste would not exceed the regenerative and/or assimilative capacities of the planet and its local ecosystems (Daly, 1996; Dietz and O'Neill, 2013). This shrinking of the economy can be evaluated in terms of reduced matter/energy throughput, as suggested by Boulding (1966), Daly (1973) and Georgescu-Roegen (1975). This can be considered the minimum definition of degrowth (Heikkurinen, 2016; Kallis et al., 2018), but it is not an adequate description in the absence of a call to politicise the economy (Fournier, 2008).

Since the transformation from a growth economy to a degrowth society means that humans must use fewer natural resources (Kallis et al., 2014), the required change also challenges capitalism as a political-economic regime because it is one based on accumulation (Foster, 2011; Boltanski and Chiapello, [1999] 2005). Equally, degrowth must target any other form of 'growth society based upon the development of productive forces' (Latouche, [2007] 2009, p. 89). Given the hegemony of neoliberal capitalism, it goes without saying that political change of this magnitude will be difficult, if not almost impossible to achieve. The contemporary degrowth movement (Martínez-Alier et al., 2010; Cattaneo et al., 2012; Sekulova et al., 2013; Kallis et al., 2012; D'Alisa et al., 2014) that has effectively begun to decolonize the growth imaginary and explore alternative practices to growth economies (see Castoriadis, [1975] 1988]; Latouche, [2007] 2009) has also come to notice this. The radical idea of a degrowth society signifies a largescale cultural reorientation, including changes in social structures, values, and activities (see Latouche, [2007] 2009). And being so, the call for degrowth touches upon the very fundamentals of how time and human energy are used in modern societies (Heikkurinen, 2016). 
This article aims to contribute to the emerging degrowth theory by offering a preliminary analysis of the kinds of activities required for a political change à la décroissance, leading to reduced matter/energy throughput, by means of true democracy and a more aware participation. For this task, the paper draws on the texts on political action of Hannah Arendt ${ }^{1}$, a Jewish political theorist writing in the twentieth century. The current article argues that the depth of Arendt's work ensures it remains relevant today. This study explains why the thoughts expressed, above all present in The Human Condition (1958) and Between Past and Future: Six Exercises of Political Thought (1961) can be very relevant for the degrowth movement that aspires to generate political change of such great magnitude, that is, reversing the foundation of modern life, namely the assumption of limitless growth ${ }^{2}$. The rest of the article is structured to first present Arendt's thoughts on action (Section 2). The article then proceeds to discuss her ideas of action in relation both to the minimum requirement of the degrowth movement, namely matter/energy reduction, and to its political purpose of more radical democracy (Section 3), while the last part is reserved for the concluding remarks (Section 4).

\section{Review of Arendt's theory of human activity}

\subsection{Activity as a response to contemplation}

In The Human Condition, Arendt ([1958] 1998) scrutinizes the entire western philosophical tradition dating back to Plato and Aristotle, and accuses it of having escaped from human praxis (vita activa) in order to find a quiet refuge

\footnotetext{
${ }^{1}$ Arendt was born in Germany in 1906 and migrated to the United States because of the Nazi persecution. She became famous for her book The Origins of Totalitarianism(1951), and in particular for the expression 'banality of evil' contained in the long article, which was later transformed into a book, Eichmann in Jerusalem (1963). The interest and the polemics that these works stirred, by virtue of the originality of historical interpretation, obscured for some time the value of more theoretical writings, which were later recognised as masterpieces of twentieth-century political theory.

${ }^{2}$ Interestingly, Arendt is seldom analysed and applied in the degrowth literature. Zoellick and Bisht (2017) have, however, included Arendt's 'Human Condition' as one of multiple theoretical perspectives on technology in their overview.
} 
in contemplation (bios theōrêtikos), which also happened to be the key premise for the Christian thought that followed the ancient philosophy. In fact, Christianity developed the belief, 'in a hereafter whose joys announce themselves in the delights of contemplation' (Arendt, [1958] 1998, p. 16). Modern subjectivism, far from inverting this trend, according to Arendt ([1958] 1998, p. 272) contributed to humans' gradual world alienation 'from Descartes and Hobbes to English sensualism, empiricism, and pragmatism, as well as German idealism and materialism up to the recent phenomenological existentialism and logical or epistemological positivism.' If we agree with Arendt's point of view, we may deduce the reason today's philosophical thought is rather absent from environmental questions, the most practical and urgent that we can imagine, which on the contrary constitute the starting place for degrowth movement's reflections.

Provided that Karl Marx represented an evident break point to the described escape from reality ${ }^{3}$, in Arendt's opinion he recanted to get completely out of the traditional path and the philosophical idealism (Arendt, [1958] 1998, p. 17):

My contention is simply that the enormous weight of contemplation in the traditional hierarchy has blurred the distinctions and articulations within the vita activa itself and that, appearances notwithstanding, this condition has not been changed essentially by the modern break within the tradition and the eventual reversal of its hierarchical order in Marx and Nietzsche. It lies in the very nature of the famous "turning upside down" of philosophical systems or currently accepted values, that is, in the nature of the operation itself, that the conceptual framework is left more or less intact.

\footnotetext{
${ }^{3}$ As it is well known, Marx departed from Hegelian system, but putting the human activity as the fundament of history, instead of the conflicts of ideas, he totally inverted his master's theoretical structure.
} 
This lack of reconceptualization is one of the main reasons why, according to Arendt, Marx fell into the contradiction of considering labour and work as the basis of human society ${ }^{4}$ or even just what differentiates men from the other animals; at the same time indicating their end as the supreme final purpose of human history ${ }^{5}$. Gorz offers a very similar interpretation, pointing out that 'Marx reduces work to labour while at the same time continuing to view it in some places as 'making works' and, at others, to forecast its abolition' ([1988] 1989, p. 22).

The latter aspect is clearly forgotten by most Marxist ideologists and above all by the Soviet Union, the People's Republic of China and the other Marxist countries, yet likeminded thinking seems to characterize much of the alternative theory and practice challenging the hegemony of growth (cf. Foster, 2015). However, this critical aspect has also been often dealt with ${ }^{6}$; a particularly interesting framing is put forward by the German group Krisis, which in its Manifesto ${ }^{7}$ writes:

The historical working-class movement, which did not rise until long after the fall of the old social revolts, did not longer struggle against the impositions of labour but developed an overidentification with the seemingly inevitable. The movement's focus was on workers' 'rights' and the amelioration of living conditions within the reference system of the labour society whose

\footnotetext{
${ }^{4}$ In a note Arendt ([1958] 1998, p. 86, n. 14) specifies: "The creation of man through human labor" was one of the most persistent ideas of Marx since his youth. It can be found in many variations in the Jugendschriften [...] That Marx actually meant to replace the traditional definition of man as an animal rationale by defining him as an animal laborans is manifest in the context'. In his Economic and Philosophic Manuscripts of 1844, Marx ([1844] 1959, p. 31) affirms: 'In creating a world of objects by his personal activity, in his work upon inorganic nature, man proves himself a conscious speciesbeing, i.e., as a being that treats the species as his own essential being, or that treats itself as a speciesbeing.'

${ }^{5}$ 'In all revolutions up till now the mode of activity always remained unscathed and it was only a question of a different distribution of this activity, a new distribution of labour to other persons, whilst the communist revolution is directed against the preceding mode of activity, does away with labour' (Marx and Engels, [1932] 1968, p. 42).

${ }^{6}$ Cf. e.g. https://libcom.org/library/abolition-labour-marxs-teachings-uri-zilbersheid.

${ }^{7}$ http://www.krisis.org/1999/manifesto-against-labour/.
} 
social constraints were largely internalised. Instead of radically criticising the transformation of human energy into money as an irrational end-in-itself, the workers' ${ }^{6}$ movement took the 'standpoint of labour' and understood capital valorisation as a neutral given fact.

Marx 'insisted that the aim of a revolution could not possibly be the alreadyaccomplished emancipation of the laboring classes, but must consist in the emancipation of man from labor' (Arendt [1958] 1998, p. 130). Arendt also noted that even Marx, who actually defined man as an animal laborans, had to admit that productivity of labour, properly speaking, begins only with reification, that is with 'the erection of an objective world of things' (Ibid., p. 102). Arendt's view on animal laborans, however, is by no means a synonym for the labouring class, but is 'the indictment of an activity, a way of life, even of a relationship to the world' (Levin, 1979, p. 523). Hence, there is a need to differentiate between different forms of human activity.

\subsection{Labour, work, and action}

In order to avoid the misleading assumptions about the role of labour, it was necessary for Arendt to distinguish three different kinds of human activity, namely labour, work, and action (Table 1). To clarify this differentiation is important not only to appreciate Arendt's contribution, but also to proceed with investigating its relevance to the degrowth attitude towards productive activities.

For Arendt ([1958] 1998), at its simplest, the first difference between labour and work is that the former is made by the whole body, whereas the hands essentially make the latter. The terms correspond to the Greek verbs ponein and ergazesthai respectively. In the words of Arendt (Ibid., p. 7), 'labor is the activity which corresponds to the biological process of the human body, whose spontaneous growth, metabolism, and eventual decay are bound to the 
vital necessities produced and fed into the life process by labor.' Therefore, labour consists of all the activities concerning life reproduction: agriculture, hunting, searching for natural products and water, finding the means for heating, maintaining the environment in a productive condition, and homes in a state of order and cleanliness. In the ancient world these activities were typically slavish: 'the institution of slavery in antiquity [was] the attempt to exclude labor from the conditions of man's life' (Arendt ([1958] 1998, p. 84). Accordingly, what characterizes the things produced by labor (p. 96) is that:

After a brief stay in the world, they return into the natural process which yielded them either through absorption into the life process of the human animal or through decay; in their man-made shape, through which they acquired their ephemeral place in the world of man-made things, they disappear more quickly than any other part of the world.

In contrast to labour, Arendt identifies work with projecting, creating, and manufacturing objects and tools that are destined to sustain over time rather than referring to objects and processes of daily consumption. Work builds the 'artificial' or human-made world, which has a fundamental function for human beings, as it gives life a sense of stability ([1958] 1998, p. 7). The protagonist of work is the "homo faber who makes and literally "wworks upon" as distinguished from the animal laborans which labors and "mixes with", (Ibid., p. 136). Even though Arendt's aim is to point out the reasons why labour and work have thrived to the detriment of action, she does not forget the importance of work's objects to human existence, as is clear from the following passage (Arendt, [1958] 1998, p. 137):

Against the subjectivity of men stands the objectivity of the manmade world rather than the sublime indifference of an untouched nature, whose overwhelming elementary force, on the contrary, will compel them to swing relentlessly in the circle of their own 
biological movement, which fits so closely into the overall cyclical movement of nature's household. Only we who have erected the objectivity of a world of our own from what nature gives us, who have built it into the environment of nature so that we are protected from her, can look upon nature as something "objective". Without a world between men and nature, there is eternal movement, but no objectivity.

It is therefore clear that in this vision, art typically belongs to work, or rather is its most extreme expression. The actual confusion between labour and work did not exist in history, as is testified by 'the simple fact that every European language, ancient and modern, contains two etymologically unrelated words for what we have to come to think of as the same activity' (Ibid., p. 80). In a similar structure to that found in ancient Greek, Latin uses the verbs 'laborare' and 'facere' or 'fabricari'; French uses 'travailler' and 'ouvrer', and German 'Arbeit' and 'Werk'. This conceptual overlap that 'all serious activities, irrespective of their fruits, are called labor' (Ibid., p. 127) matches with the origin of contemporary consumerism. Goods are produced without interruption to be used, destroyed, and substituted in a very short period of time, as if they were perishable products. The modern consumer society devours more and more natural and human resources, as if it were a young organism, needing abundant nourishment to grow, survive and stay healthy. This, and the following reasoning of Arendt (Ibid., pp. 125-126), could represent an early critique of the growth economy:

In our need for more and more rapid replacement of the worldly things around us, we can no longer afford to use them, to respect and preserve their inherent durability; we must consume, devour, as it were, our houses and furniture and cars as though they were the "good things" of nature which spoil uselessly if they are not drawn swiftly into the never-ending cycle of man's metabolism with nature. It is as though we had forced open the distinguishing 
boundaries which protected the world, the human artifice, from nature, the biological process which goes on in its very midst as well as the natural cyclical processes which surround it, delivering and abandoning to them the always threatened stability of a human world.

While in the Greek polis, labour was necessary yet a rather despicable occupation to be left to slaves by rich people owning them, it has now become the fulcrum of our social organization, transforming each citizen into a modern slave. Not in the sense that all workers are becoming peasants, which on the contrary is increasingly disappearing, but that work and the whole contemporary life took the typical characterisation of labour: 'labor and consumption are but two stages of the same process, imposed upon man by the necessity of life, [which] is only another way of saying that we live in a society of laborers' (Ibid., p. 126). In fact, Arendt writes:

Whatever we do, we are supposed to do for the sake of 'making a living'; such is the verdict of society, and the number of people, especially in the professions who might challenge it, has decreased rapidly. The only exception society is willing to grant is the artist, who, strictly speaking is the only 'worker' left in a laboring society. [...] As a result, all serious activities, irrespective of their fruits, are called labor, and every activity which is not necessary either for the life of the individual or for the life process of society is subsumed under playfulness (Ibid., pp. 126-127).

In the described process, advanced mechanisation plays a fundamental role, because 'guided by utilitarianism homo faber has created automated processes without a clearly distinguishable beginning and end', so that 'homo faber is reduced to the animal laborans, enslaved by automated processes, built by himself' (Zoellick and Bisht 2017, pp. 4-5). The main reason for this evolution, or 'devolution' (to use a more accurate term), according to Arendt, 
is the desperate human desire for immortality. On the other hand, she was quite eager to elaborate on, and thus respond to, immortality as an inquisition from the ancients by developing her concepts on natality and mortality accordingly. In her work, Arendt not only gives political meaning to the natality and the 'new beginnings' inherent in birth itself, but to death and mortality. Only action through natality is not perishable. But despite the dark realism in The Human Condition Arendt among others had demonstrated great hope, attached to action and natality. Hence, to the human condition of plurality reflected in the political life itself. This places Arendt, as previously noted by Canovan in the introduction to The Human Condition, as a thinker and theorist of the 'beginnings', or political change of great magnitude.

Action, according to Arendt, represents a precondition for politics, tantamount to freedom, enforces public space and is mostly memorable, which goes against the mortality and perishability of the other two modes of activity: labour has a daily horizon; work creates durable (but not necessarily sustainable) objects, which give stability to human environment, not to human existence itself. She describes action in The Human Condition as follows:

Action, the only activity that goes on directly between men and without intermediary of the things or matter corresponds to the human condition of plurality, to the fact that men not Man, live on the Earth and inhabit the world. While all aspects of the human condition are somehow related to politics, this plurality is specifically the condition - not only the conditio sine qua non, but the condtio per quam of all political life (Ibid., p. 7).

That being so, it seems that plurality is a central concept from which the concept of action arises. For Arendt, plurality signifies membership of the political community where one acts and speaks in the public sphere (Arendt, [1951] 1985, p. 297). Accordingly, the public space (as opposed to the private one) holds immense importance for Arendt. Work and labour however belong 
within the private and social sphere, a distinction she strictly maintains throughout her work. From this aspect stem both the memorability of action and the durability of work, which is situated within the private or social sphere, and thus is not as memorable as action itself. Action is located within the public sphere and is always in relation to the action of others. It rises out of the plurality of differences and uniqueness of actors including their deeds. It is what space of appearance consists of, and an expression of the unique distinctness of the who and not what is found through action and speech in the public sphere (Arendt, [1958] 1998).

\section{[PLEASE INSERT TABLE 1 ABOUT HERE]}

Benhabib ([1996] 2003), however, criticizes Arendt's three-layered spatial distinction and considers it untenable. Arendt's justification and reasoning on the clear-cut division of the public, social, and private spheres is a result of the danger she foresaw from the rise of the social (described in a chapter of the same title in The Human Condition, Ibid. pp. 38-49). According to Arendt, this phenomenon had blurred the boundaries between the private and public space, and had contributed towards its erosion by leading to fully-fledged totalitarianism as an extreme and destructive phenomenon. The social in the chapter title is for Arendt pre-totalitarian as it relates to the uniformity or lack of differences, erosion, and shrinking of the public space by blurring the limits between private and public. As examples of such a blurring she mentions the role of households and the activities of production that had contributed towards blurring the distinction between the individual who is abstract and uniform and the role of citizens who are active custodians of opportunity among the general public (Arendt [1958] 1998).

Furthermore, Arendt considers that within the social sphere, similarly to the private one, people can choose with whom they wish to associate, meaning that discrimination is legitimate if it remains internalized. Nevertheless, she is preoccupied with how to prevent this discrimination reaching the public 
sphere where it is becomes very destructive and erodes it (Arendt, 2003, pp. 193-213), leading to destruction on a scale similar to that of the concentration camps. She considers that ideally the public or political sphere should consist of equality through difference, rather than resulting from certain groupings being that even class, as Marx also suggested as well (Arendt, [1963] 1990; 1951 [1985]). It is in this public sphere that the power of the people and political community is upheld through its members being able to freely act and express their viewpoints. Arendt states that 'in acting and speaking, men show who they are, reveal actively their unique personal identities and thus make their appearance in the human world' ([1958] 1998, p. 179).

In igniting change or novelty through action, the public sphere is reinforced and that is of central importance to Arendt. This focus on the public however, guards against the 'dark' aspect of plurality that might be reflected in the existence of bureaucracy and ideologies. The main purpose of the public sphere is to allow people and communities to freely express their 'unique distinctness' through acting and speaking (Arendt [1958] 1998), p. 57). But for the public sphere to function well, solid structures and systems are required (Ibid.). This includes the formal (state) and informal (various interest groups such as: NGOs, environmental movements, indigenous communities etc.) bodies. For Arendt, it is precisely speech and political action that distinguish human beings from other animals, and expressing them is the only way for individuals to simultaneously exist as unique units and exist in a community alongside others. Public space is multidimensional for Arendt in a similar way to plurality. It is dynamic and composed of various layers and interrelationships. On the one hand, public space reaffirms the durability of the public institutions, and on the other hand, enforces an unfettered freedom through unpredictability of action. The balance between these two aspects is what provides for free public space and the space of appearance where unique persons may act and speak freely, and hence create relationships and exchange opinions. This is what accounts for substantive democracy for Arendt, and which has its foundation in her idea of political equality first 
presented in The Origins of Totalitarianism and elaborated upon in the volume On Revolution. The main criticism of the French Revolution for Arendt was that it shifted from political to social concerns. For Arendt, this has set humanity on a roller coaster ride. Moreover, the thinking tradition has been most responsible for opening up the profound abyss created between action and thinking on one side, and the past and future on the other (Arendt, [1954] 1961 p. 7).

Political equality for Arendt is based on differences (rather than inborn equality as the French Declaration suggests): different actions, different speech and words, different viewpoints, and different opinions, out of which political equality emerges to be represented in stable and durable institutions. In that sense, the other facet of freedom along with unpredictability-which is a characterizing element of the public space and space of appearance-is not at odds with political equality, but rather reaffirms it by allowing for differences to peacefully co-exist. The end result is the building of stable institutions, which will sustain over time and in the face of changes to society based on differences rather than on sameness (Arendt, [1951] 1985). Owing to a fear of mass society and uniformity being a precursor to totalitarianism, Arendt insisted fiercely on differences and uniqueness as the basis of political action. The public space comprising plurality of differences with action and speech in between counteracts what Arendt saw as the greatest danger, the erosion of public space prompting uniformity and control to take over. Uniformity for Arendt represents characteristics that might be found in mass society (which we interpret as pre-totalitarian leading to totalitarianism), 'and can occur under conditions of radical isolation and mass loneliness (Ibid., pp. 474-479), where nobody can any longer agree with anybody else, as is usually the case in tyrannies. But it may also happen under conditions of mass society and or mass hysteria, where we see all people suddenly behave as though they were members of one family' (Arendt, [1958] 1998, p. 58). It is clear that 'uniformity' for Arendt is a precondition for a totalitarian society, a form she is extremely critical of. 
A number of scholars, and particularly those adopting a feminist perspective, have recently stated reservations about the Arendtian concept of action on the grounds that it tends to draw a clear demarcation between the public sphere and the spheres of economy, life, and ecology. Kristeva (2001, p. 162), for example, wants

to emphasize the limitations to Arendt's diatribe against a society that is consumed by the economy and that therefore destroys the freedom of the polis. Other limitations also emerge in her approach to the body as well as in her lack of attention to psychic life and intimacy, which she considers to be hybrid relics of subjectivism and the loss of transcendence.

So that 'the political theorist [Arendt] managed to neglect the plural and possible economies of pre-political freedom that disclose "the social"'(Ibid.). In other words, Arendt forgot the value of pre-political forms of interaction for freedom when she denigrated them as 'the social.'

Benhabib extends that problematisation of an apparently too marked and schematic Arendtian distinction between the 'private realm' and 'public sphere' or between 'the social' and 'the political', but she also offers a convincing interpretation. If, on first sight, Arendt seems to forget that 'the rise of the social was accompanied by the emancipation of these groups [women, slaves, laborers, non-citizen residents] from the "shadowy interior of the household" and by their entry into public life' (Benhabib 2007, p. 90), a more accurate scrutiny shows that 'if one locates Arendt's concept of "public space" in the context of her theory of totalitarianism, it acquires a rather different focus than the one dominant in The Human Condition' (Ibid., p. 93). In fact, 
the 'associational' view of public space suggests that such a space emerges whenever and wherever, in Arendts words, 'men act together in concert'. On this model, public space is the space 'where freedom can appear'. It is not a space in any topographical or institutional sense: a town hall or a city square where people do not 'act in concert' is not a public space in this Arendtian sense. But a private dining room in which people gather to hear a Samizdat or in which dissidents meet with foreigners become public spaces; just as a field or a forest can also become public space if they are the object and the location of an 'action in concert', of a demonstration to stop the construction of a highway or a military airbase, for example.

These diverse topographical locations become public spaces in that they become the 'sites' of power, of common action coordinated through speech and persuasion (Ibid., p. 93).

These remarks are of evident value in the search for activities for degrowth, clarifying what the Arendtian concepts of political action and the public sphere actually mean.

\subsection{Action as political change and rebirth}

For Arendt, the main characteristics of political action are 'unpredictability' and 'irreversibility' (Arendt, [1958] 1998). Unpredictability represents a miracle bringing novelty and political change to the forefront. For Arendt, action is a miracle exactly because of its unpredictable outcome, which brings us back to the ideas of natality and new beginnings, and consequently, the ability to bring novelty to the world through action. Second, unpredictability has a revelatory character because it reveals the uniqueness of the one who acts, that is, the actor itself. In that sense, Canovan ([1992] 1994) considers this unpredictability as a double unpredictability; as it encompasses the actor 
itself and his/her actions towards others and the political community as such where the action acquires its expression. This, is however extremely relevant for creating relationships within the plurality and public sphere according to Canovan ([1992] 1994, p. 293).

In fact, it is quite obvious that when humans meet in order to make common decisions and develop political projects, interactions are so multifaceted and complex that they cannot be certain of the result, which may even appear very destructive. In the case of the global [growth] capitalism (see e.g. Scott, 1998; Ruuska, 2017) where decisions have far reaching consequences in time and place, this fear of creating destruction is legitimate. The solution, according to Arendt, would not be the outsourcing of responsibility to the invisible hand, and hence to attempt to refrain from politics, but the opposite. The remedies, according to Arendt, lie in creating dialogue and communication without prejudice and stereotypes but with an understanding of and responsibility for one's actions. In the prologue to The Human Condition, she expressed a basic premise 'to think what we are doing', which reflects the responsibility based on understanding, solidarity, and reconciliation with the world as it is, acting in good faith and being ready to judge the effects of one's actions with indulgence. This is what 'amor mundi', or for the love of the world, means for her, which incidentally, was the working title of her central volume The Human Condition (Arendt and Jasper, [1985] 1993).

In her theory of action, the change from labour and work to action is of such great magnitude that Arendt compares it with a second birth, calling political action a rebirth. For Arendt, new beginnings or being able to start something anew is ingrained in the idea of 'natality' and represents political birth as opposed to the mere physical birth that is expressed throughout liberal political tradition. Commencing political action is similar to entering into genuine life and the start (archein) is the most important phase, compared to 
the conclusion, that is ever known before it occurs ${ }^{8}$. For Arendt, political action is not just the noblest activity for humans, it is the only one granting authentic life, developing real identity, giving the pleasure of interaction, and allowing a diversity of ideas to have consequences in reality. Solely through political action and community life, humans can experience power in its most positive form, which is the capacity to leave a mark - albeit an unpredictable one - on history. That is, for a life of an individual to be worthwhile, it must be narrated like a story that acquires a sense only when told by one person to another. Therefore, it cannot be solipsistic, where only one's own mind can be said with certainty to exist. Human individuals embedded in their social practices burgeon in a collective surrounding, where they relate themselves to other members of the community.

In her last work, The Life of the Mind (1978) - her unfinished spiritual testament - Arendt confirmed her belief that in everyone's existence it is indispensable to distinguish the private life from the political one. The former is the kingdom of personal affections, the place for loving relatives, friends, maybe God, while the latter means essentially to act, obviously respecting others and their opinions. To devote oneself sentimentally to ideologies, parties, groups, nations, and collective entities is dangerously misleading. Being in the world, therefore, does not correspond to an impulsive action without thought and reflection; on the contrary. Arendt's aim is to overcome the long divorce between philosophy and politics, finding a modern union without precedents in western history of theoria and praxis (critically looking at Marx's example), which cannot be simply copied from the Greek polis to address present-day challenges.

\footnotetext{
${ }^{8}$ Although Arendt herself was not a feminist, she offered feminism a crucial idea, the one of natality. For instance, the Italian feminist philosopher Adriana Cavarero, also inspired by Luce Irigaray, criticizes the western cultural tradition, beginning with Plato, as did Arendt. For Cavarero its core is the masculine principle of death (mortality versus immortality) and consequently it ignores the feminine principle of natality. Moreover, most feminist thinkers tend to reject the abstract image of a universal, ideal human being, obviously man and not woman; exactly the same accusation that Arendt levelled at Plato and his followers.
} 


\section{Implications for the degrowth theory and movement}

\subsection{Acting politically}

If degrowth aims to progress beyond a series of simple ecological interventions, find the philosophical roots of the present pervading productivism/consumerism, and so create the theoretical premise for Latouche's decolonisation of the imaginary, then Arendt's contribution can be invaluable. She dedicates an entire chapter to this matter (Arendt [1958] 1998, p. 126-135), which highlights the undesired effects of confusing work and labour, at the same time marginalizing political action.

The degrowth movement is seeking to generate political change of great magnitude by challenging the ideology and hegemony of economic growth (Latouche, [2007] 2009). It is a political project in the strongest sense of the term, one which seeks to build convivial societies that are autonomous and economical in both the North and the South (Latouche, [2007] 2009, p. 32). In the words of André Gorz, we are speaking of 'a politics of time which embraces the reshaping of the urban and natural environment, cultural politics, education and training' ([1991] 1994, p. 61). The project is so deep and global that it could be compared to the second birth of the human civilisation, which for Arendt could be the beginning of a conscious, powerful political participation spanning the globe.

When describing degrowth, Latouche ([2007] 2009, p. 85-86) notes that 'it is not only that the two repressed components of the vita activa - the work of the artist or artisan and political activity in the true sense-will be restored to the same dignity as labour; the vita contemplativa itself will be rehabilitated.' Presumably by vita contemplativa Latouche means theoria, which Arendt desires to reunite with praxis (see section 2.3) but is using terminology that does not coincide with Arendt's. 
Moreover, for Latouche (Ibid.), active collective participation in full democracy is essential for a future degrowth society, and he often refers to Castoriadis (1922-1997), the Greek-French philosopher, social critic, economist, and psychoanalyst, whose writings on autonomy and social institutions have been influential in both academic and activist circles. It is noteworthy for scholars theorizing degrowth that Arendt and Castoriadis are quite similar in that they assign central importance to the collective 'imaginery' as the fundamental tool to change the existing reality and to create unused forms of coexistence (see Latouche, [2007] 2009, p. 93). Despite this evidence, Castoriadis never refers to Arendt in his main works, and indeed the whole degrowth movement has rather neglected the contribution of a giant of twentieth-century thought.

The similarity becomes even more evident if comparing the respective conceptions of praxis:

We term praxis that doing in which the other or others are intended as autonomous beings considered as the essential agents of the development of their own autonomy. True politics, true pedagogy, true medicine, to the extent that these have ever existed, belong to praxis. (Castoriadis [1975] 1988, p. 75).

If degrowth essentially depends on 'the in-depth self-transformation of society and its citizens' (Latouche [2007] 2009, p. 67), it becomes very evident that it implies a general involvement of people in the Arendtian way of action.

A proposal that is worthy of very serious consideration by the degrowth followers, and can be considered an actualisation of Arendt's ideas, is 'ecomunicipalism' (Ibid., p. 44; see also Bookchin, 1980; 1982): it shows how a permanent process of collective, democratic decision making on strategic 
goals may occur. In other words, the degrowth perspective guided by the model of direct, generalized participation in politics, proposed by Arendt, Castoriadis, and Bookchin (with three different philosophical frameworks) is the best guarantee against the risk that increasing ecological catastrophes can provoke a form of 'eco-fascism', which implies a dystopian, authoritarian, totalitarian government facing environmental emerging dangers, but excluding citizens from the choice processes, on the grounds of their supposed technical ignorance and the absolute urgency of action (Latouche [2007] 2009, p. 95; Castoriadis, 2005, p. 246; see also Beck [1986] 1992).

Obviously dedicating a great part of life to political engagement is strictly linked with the exit from the slavery of 'laborized', work dominated by labour, which despite technological innovations still occupies too much time and human energy. In fact, '[a] dramatic reduction in working hours is [not only] a first defence against flexibility and job insecurity' (Latouche [2007] 2009, p. 81), but part of "primarily social choices resulting from the cultural revolution brought about by de-growth. Giving citizens more unconstrained time in order to allow them to blossom in their political, private and artistic lives, and play or contemplation, is the precondition for developing a new form of wealth' (Ibid., p. 82).

It would be really interesting to compare this need for time liberation to Bataille's perspective, which also condemns human enslavement to labour in the hope of limitless growth, and which also aims at a collective time and energy expenditure, even though more than political action, it assumes the forms of fantasy, festivals, exuberance shared dépense (Bataille [1967] 1988, pp. 45-46):

Nothing is more different from man enslaved to the operations of growth than the relatively free man of stable societies. The character of human life changes the moment it ceases to be guided by fantasy and begins to meet the demands of undertakings that 
ensure the proliferation of given works. [...] The serious humanity of growth becomes civilized, more gentle, but it tends to confuse gentleness with the value of life, and life's tranquil duration with its poetic dynamism. Under these conditions the clear knowledge it generally has of things cannot become a full self-knowledge. It is misled by what it takes for full humanity, that is, humanity at work, living in order to work without ever fully enjoying the fruits of its labor. Of course, the man who is relatively idle or at least unconcerned about his achievements - the type discussed in both ethnography and history - is not a consummate man either. But he helps us to gauge that which we lack.

The concept and its relevance for degrowth are discussed in chapter 17 of Degrowth: A vocabulary for a new era (D'Alisa et al., 2014).

Perhaps, however, the strongest connection between Arendt and degrowth is presented by André Gorz ${ }^{9}$. It is not by chance that his very important book Critique of Economic Reason (Métamorphoses du travail: Quete du sens) begins by quoting Arendt (Gorz [1988] 1989, p. VII). The French thinker develops his reasoning from Arendt's conviction that we are confronted with the prospect of a society of labourers without labour: a forthcoming tragedy (Ibid., p. 8). Gorz's solutions perfectly align with degrowth (Ibid., p. 192):

The generalized reduction of working time amounts to a choice as to the kind of society we wish to live in. This can be seen from its two inseparable objectives: (a) that everyone should work less, so that everyone may work and may also develop outside their

\footnotetext{
9 'Intellectually, the origins of degrowth are found in the Continental écologie politique of the 1970s. Andre Gorz spoke of 'décroissance' in 1972, questioning the compatibility of capitalism with earth's balance 'for which ... degrowth of material production is a necessary condition'. Unless we consider 'equality without growth', Gorz argued, we reduce socialism to nothing but 'the continuation of capitalism by other means - an extension of middle-class values, lifestyles and social patterns' (Giorgios Kallis, The Left should embrace degrowth, https://newint.org/features/web-exclusive/2015/11/05/leftdegrowth).
} 
working lives the personal potential which cannot find expression in their work; (b) that a much greater proportion of the population should be able to have access to skilled, complex, creative and responsible occupational activities which allow them continually to develop and grow.

The complete reconfiguration of mentality and convictions required by degrowth may be compared to the spirit with which the colonists arrived in America, as described by Arendt ([1963] 1990, p. 173).

No theory, theological or political or philosophical, but their own decision to leave the Old World behind and to venture forth into an enterprise entirely of their own led into a sequence of acts and occurrences in which they would have perished, had they not turned their minds to the matter long and intensely enough to discover, almost by inadvertence, the elementary grammar of political action and its more complicated syntax, whose rules determine the rise and fall of human power. Neither grammar nor syntax was something altogether new in the history of western civilization; but to find experiences of equal import in the political realm and to read a language of equal authenticity and originalitynamely, so incredibly free of conventional idioms and set formulas - in the huge arsenal of historical documents, one might have to go back into a very distant past indeed, a past, at any rate, of which the settlers were totally ignorant.

An interesting and useful indication for degrowth political action may come also from the comparison between French and American revolution offered by Arendt. According to her, Americans 'to the extent that they had a positive notion of freedom which would transcend the idea of a successful liberation from tyrants and from necessity, this notion was identified with the act of foundation' (Arendt [1963] 1990, p. 234). Which means creating something 
absolutely new, but in direct alliance with others. The same difference reflects 'the conflict between the two systems, the parties and the councils, came to the fore in all twentieth-century revolutions. The issue at stake was representation versus action and participation. The councils were organs of action, the revolutionary parties were organs of representation' (Ibid., p. 273).

Overall, Arendt's philosophical thoughts on the essence of action constitute an antidote to bitter disillusionment in that they anticipate a victorious revolution, and also to the risk of turning degrowth into blind faith in the easy and inevitable redemption of humanity after the sinful epoch of growth and consumerism. It might be that the degrowth movement will face some of the same challenges that tend to confront all political movements, namely questions of ideology and the need to predefine the aims of action. Arendt offers more practical advice to meet this challenge. Arendt holds that the origin of most social problems is connected to the disappearance of action. Thus, at its simplest, the main message of Arendt to the degrowth movement could be that more political action is needed. Action, as defined by Arendt, could be utilized as a foundation for the degrowth movement. Its unpredictability could provide meaning and substance to the somehow rigid ecological economics and social sciences based on numbers and statistics.

\subsection{Understanding 'degrowth' in the plural}

The very ambitious task of rebirth through political activity described above, involves seeking out the effective means and desired ends (see D'Alisa et al., 2014). That process corresponds to a non-ideological approach to action, without a prefixed route, as recommended by Arendt. This prompts the question of what kind of political action might constitute degrowth.

Arendt's theory of action can help the degrowth movement with this question. First of all, the three-fold conceptualization referencing labour, work, and action that Arendt offers, can be used as an analytical tool to distinguish 
different forms of action for degrowth. In the spirit of plurality, however, degrowth should not be limited to one correct type of activity. Arendt's key message is that it is dangerous and pointless to come back to a closed ideology that is certain about the end and the purpose of history, and that it is dangerous and pointless to act politically with a certainty one's efforts will produce a good and quick outcome. This is particularly the case for such thinking that replaces the growth ideology with the degrowth ideology. Accordingly, one practical implication of Arendt would be to consider degrowth action always in the plural, that is, to talk about degrowth movements and activities of degrowth. The most obvious and important reason for this plurality is the danger of degrowth turning into another totalitarian frame characterized by tyranny and dictatorship. While degrowth could challenge all activities of the human condition through the lens of matter/energy throughput, it can also be interpreted as an ideology with totalitarian goals. That is, if every act must lead to lower matter/energy throughput, degrowth becomes the exact opposite of Arendt's conception of freedom and action. Of course, this absurd claim is not made in this study, mainly because constant reduction leads to zero, which signifies decay and eventually death of all human life. This is not only impossible (given that most humans cannot even give up their automobiles and annual holidays abroad), but also undesired from human and holistic ecological points of view. However, in order to continue and respect diverse life on Earth, the matter/energy throughput must reduce on the global level. The laws of thermodynamics applied to society (see e.g. Georgescu-Roegen, 1975) can be interpreted as restrictive (but perhaps not totalitarian) because they set limits to human freedom and action; but they can also be considered emancipatory. After all, one of the underlying aims of degrowth, as illustrated in sustainability studies, is to contribute to inter- and intra-generational justice, as well continuity of life on Earth, which is not solely determined by the freedoms of human beings.

Even if it might be tempting to draw parallels between the totalitarian growth imperative and its means of efficiency and the degrowth movement and its 
call for sufficiency, they two are not comparable. First, the former is based on the idea of scarcity, while the latter assumes limits (see Eskelinen and Wilén, 2018). This is an important distinction because without the premise of limits, the non-human world can be exploited to the last milligram of resource (e.g. fossils) useful to humans. Such an approach would not only radically limit the freedom of non-human beings but also fellow humans, as the negative consequences of climate change do not distribute equally. Secondly, efficiency as the means of growth cannot simply be replaced by sufficiency, as the latter calls into question what is actually needed, that is, what is sufficient. The former again is insatiable in the sense that a process or society will never reach a state of efficiency but will always seek to improve its inputoutput ratio. This leads to an ever-increasing instrumentalisation of earthbound beings and directs attention away from the question of how much is actually sufficient. Lastly, in stark contrast to the pursuit of efficiency, sufficiency is nothing universal or absolute but is negotiable and contextual (Bonnedahl and Heikkurinen, 2018), making it a less than ideal match for totalitarian aims.

In addition to talking about degrowth movements and activities of degrowth, the plurality in degrowth could manifest in engaging with different actors and stakeholders in diverse spheres of social life. That is, to interact politically in both vertical (bottom-up and top-down) and horizontal (bottom-bottom and top-top) terms. Degrowth plurality signifies the acceptance and inclusion of opinions and viewpoints that do not always converge. This pluralism differs from the status quo in growth-based societies in that degrowth should allow pluralism only within the ecological limits. That is, accepting limits to economic growth, or to ever-increasing matter/energy throughput is the linchpin of the degrowth movement. Determining the desired objectives for and most suitable means of forming society should then happen naturally as a result of wide-ranging, inclusive dialogue in society.

\subsection{Linking monetary transactions to growth}


In the Arendtian three-fold conceptualization of activity, when human time and energy are directed to working in the fields and renovating a house, for instance, political action is neglected. This is quite understandable, particularly in a setting where political action is not connected to labour and work. Today, engineers, doctors, cleaners, farmers, cooks, scientists - in short, all those employed outside of politics - have become de-politicised. In the current context, characterized by a system of highly specialized and depoliticised labour and work, the labour and work of an aeronautical engineer or banker who begins cultivating his or her own plot of land and growing food, at the same time undertaking reparation work instead of purchasing new products could be interpreted as a political act. In other words, changing from high status and highly paid work/labour, such as banking, to low status and low paid work/labour would arguably have political relevance. In fact, one of the aspirations of degrowth is to make such interpretations and hence repoliticise the realms that have been de-politicised (see e.g. Asara et al., 2015; Swyngedouw, 2015).

Arendt was writing about human activity ([1958] 1998) before the degrowth call for ecological, low-throughput lifestyles, and she did not consider that the labour and work forms of action could, in fact, be very political in nature. Their political importance is highlighted in these times of global capitalism, where large parts of human effort are commercialized and made to serve the interests of growth and competitiveness. In other words, what might be considered political action, is highly dependent not only on the actor itself, but also the time and place in which the activity occurs.

The foundation of the degrowth movement is the call to reduce matter/energy throughput (e.g. Georgescu-Roegen, 1975). At its simplest, this means that the non-human inputs (often referred to as resources) that enter human society, as well as the non-human outputs (often referred to as waste) that exit human society, must reduce. The main reason behind this call is the finding that the 
biospherical metabolism cannot handle this much human intervention in the natural processes. In other words, humans are using too many resources, that is, they are using them faster than they can renew them, and emitting too much waste, in that they are producing a volume of waste that cannot be absorbed into the Earth's ecosystems. The main driver of the increased matter/energy throughput is economic growth (see Georgescu-Roegen, 1975; Daly, 1996; IPCC, 2014); hence the degrowth movement.

The current economic system is such that it commodifies and instrumentalizes more or less everything for the purposes of economic growth. Global capitalism, as the current dominant economic order is often called (see e.g. Scott, 1998), not only produces but also requires further growth (Ruuska, 2017). As a consequence of this, the economic actors and regime in favour of capitalism, seeks to bring all human activity (including political action) inside the economic frame so that it can be made to serve the interests of capital and capitalists; and the most effective means to achieve that is through the monetization and professionalization of human activity so that it can be traded in the market, with a progressive loss of autonomy for the citizens, as Illich underlined ([1973] 1990, 1978). This means that previously reciprocal relations are turned into market relations, or transactions, and '[a] market necessarily reduces quality to quantity via the price mechanism and promotes standardization; in markets, money talks, not people' (Scott, 1998, p. 8). Arendt would most certainly characterize this as a main feature of tyranny, as it results in unification rather than uniqueness, and brings the actors of the public to the private sphere. It can be seen as the opposite of genuine action, which both through uniqueness and distinctness of the actors finds the power in the political space. It also considers plurality and freedom as its main characteristics. Within market-based capitalism, labour, work, and activity all become means to serve the purposes of growth and (national or corporate) competitiveness, despite the good intentions of their actors. Moreover, problematically, growth is the driver of ecological destruction. 
Another problematic dynamic of the current economic model is that transactions are largely monetized and based on debt with interest: 'In capitalism, "money" is a universal equivalent, both a standard of price and means of exchange, so it can appear as a store of value and be loaned for a percentage charge over time (interest) i.e. function as capital' (Nelson, 2016, p. 3, see also 2001). As there is interest on the debt, it means that repaying debt requires more money than was initially borrowed, and for that money to be available demands the growth of an economy. Moreover, to create economic value exchanged in the form of money, objects in the world must first be monetized and turned into commodities that can then be exchanged for the accumulation of money, or capital. These micro-level transactions are then what accrue and manifest as economic growth on aggregate levels, often measured as GDP and GWP ${ }^{10}$.

Within this rationale, it should be noted that the distinction between paid and non-paid activity is crucial for the purposes of degrowth. All activity that is measured and compensated in monetary terms contributes to the capitalist agenda of growth. In ecological economics, this circulation is conceptualized with the notion of the rebound effect, or Jevons paradox (Alcott, 2005; Lorek and Fuchs, 2013). The main issue with the rebound effect is that savings made in one place tend to rebound to another. That is, if a household saves energy by reducing room temperatures or the use of air conditioning, and hence saves money on its electricity bill, the householders will use the money on something else that will use resources at the same rate or an even higher one; perhaps a family will fly to Thailand for a vacation. Even if they saved the money in a bank account and did not use it themselves, someone else uses the money for them, namely an investor. Money in the bank does not just sit there

\footnotetext{
${ }^{10}$ It is important to note here the role of debt with regard to capitalist growth/growth of capital can be seen in different ways. In a Marxian view, for instance, debt allows for the realization of surplus value in the form of money, and moreover enables capitalists to greatly stretch the limits of the accumulation of capital (because credit allows investment beyond past profit levels). But in this view, debt is not the cause of surplus value production and accumulation. Paradoxically, under conditions of capitalism, debt increases the wealth of the debtor, rather than diminishes it. These comments hold true at least for capitalists. National debt and the debt of consumers/wage earners require separate discussions, as do their possible relations to economic growth.
} 
in the account (as the bank needs to pay interest to the account holder) but is constantly used for further investments, hence contributing to economic growth. Hence, the assumed saving is not really being saved, outside the accumulation processes of the economy.

The case would be quite different if the energy for the household were not purchased from the market but rather produced by the dwellers themselves. This is of course the same case with energy and food production. If the produced energy and food are used directly rather than being monetized, then they will never enter the capitalist market that only has one direction, further growth ${ }^{11}$. In the case of demonetized action, matter/energy savings could be safeguarded from the growth machine. People engaging in demonetized action would not have to act as monetary workers or labourers as much since they would need less money to safeguard subsistence. Therefore, it is important to note that all human activity within the current frame of capitalist society, be it labour, work, or activity is problematic from the point of view of reducing matter/energy throughput. The analysis above indicates that monetary transactions in an interest debt-based capitalist society tend to eventually contribute to economic growth that is ecologically unsustainable.

\subsection{Demonetizing activities}

While following the Arendtian analysis on the origins of meaningful political change, which emphasizes the utmost importance of action, this article also notes the importance of labour through physical activity such as community supported agriculture, and work as an arena, for example, for building offgrid energy systems, that are central to degrowth. Furthermore, while this article accords with Arendt's insight that the origin of problems in the human

\footnotetext{
${ }^{11}$ Of course, the recent financial crisis of 2007 is an example of when a capitalist market has destroyed value and shrunk, but only for a while. Within neoclassical economics, this is known as a 'market failure'. Critical economists see these apparent failures as basic working mechanisms of markets for further growth. Arguably, the pursuit of growth does not end after a collapse of great magnitude.
} 
condition is connected to the disappearance of action, this study adds a distinction between paid and non-paid activity in the political analysis. That is, it seems to make a great difference to the aims of degrowth whether human activities take place within the frame of monetary transactions.

However, it is certainly true that some large-scale effects can be achieved from political action, as suggested by Arendt, even if paid. For instance, working in the European Union or the United Nations on reducing matter/energy throughput can certainly be worthwhile. However, it cannot be denied that such political action is at the same time contributing to harmful growth and increasing throughput. This paradox is of course also present in the life of degrowth academics who fly to conferences to tell people why academics should not fly to conferences because doing so involves using scarce resources and radically adds to the waste in the form of climatedamaging emissions. After all, Arendt pleads a collective, direct political action, which does not delegate to institutions, but itself continuously institutionalizes new forms of participation, representing the strongest constituent power.

If one looks at the other two modes of activities in the Arendtian frame, namely labour and work, it is apparent that they have similar and even more disastrous effects when taking place within the monetary frame. Working on a construction site or for an industrial farmer is not only problematic as it contributes to economic growth, but also as it takes precious time and energy away from political action. However, it goes without saying that people must have shelter and food, but to deliver primary needs does not require paid labour or work, because all the needs can be met outside the neoliberal capitalist frame. 'Demonetization is not another utopia, but the logical consequence of an analysis of the causes of economic growth, the requirements of degrowth, and a subsequent steady state' (Exner, 2014, p. 23). As Exner (2014, p. 23) notes, 'only reciprocity allows democratic governance and participatory planning.' 
Naturally, reciprocity cannot be taken for granted in a democracy, as is illustrated in Mauss' famous essay about ancient peoples and their present counterparts who find themselves outside western 'civilisation' (Mauss [1950] 2002, p. 54):

The punishment for failure to reciprocate is slavery for debt. At least, this functions among the Kwakiutl, the Haïda, and the Tsimshian. It is an institution really comparable in nature and function to the Roman nexum. The individual unable to repay the loan or reciprocate the potlatch loses his rank and even his status as a free man. Among the Kwakiutl, when an individual whose credit is poor borrows, he is said to 'sell a slave'. There is no need to point out the identical nature of this and the Roman expression.

At the very beginning of his book, Mauss clarifies that reciprocity in the examined societies form a system of 'total services, apparently free and disinterested but nevertheless constrained and self-interested' (Ibid., p. 4). Although 'such services have taken the form of the gift, the present generously given even when, in the gesture accompanying the transaction, there is only a polite fiction, formalism, and social deceit, and when really there is obligation and economic self-interest' (Ibid.).

Currently, work and labour, particularly when paid, are diminishing political action for degrowth. Hence, an important aspect for degrowth of the analysis here is to first acknowledge the effects of different modes of activity in terms of matter/energy and then find a balance between them. That is, human societies require all labour, work, and action, as mere political action does not produce the necessary food and shelter for survival. These activities, however, should not be monetized but exchanged in a reciprocal manner. In other words, different types of activities should be brought into a certain relation by way of action (political deliberation, e.g., on the distribution of different types of 
labour in a community or society), which notably involves cooperation, or, to put it differently, collective reciprocity. Problematically for degrowth, however, Arendt did not make a distinction between paid and non-paid activity (as her analysis transcends any materialism of paid and unpaid work), which of course is only a problem for those who argue for Arendt's relevance in this particular matter ${ }^{12}$. This article argues that this distinction is crucial for the degrowth movement: for reducing matter/energy paid and non-paid are not equal.

While emphasizing the role of non-paid activity for degrowth, it is important to remember that an excess of labour and work, be it paid or non-paid, takes precious time that could be dedicated to political action (in its Arendtian sense). However, non-paid labour and work can also be important political actions, when a growth-driven monetary and redistribution system is in place. What is perhaps important for the degrowth movement is to find a balance between activities that enable life outside the growth society, that require both labour and work, but first and foremost engage in political activity. In an ideal situation, these actions are non-monetary, so as to avoid contributing to the growth economy. The non-paid labour and work support subsistence, which in turn enables political action, which without doubt is for Arendt a nonprofessional activity, and therefore non-paid. Another central facet of nonpaid political action is an increased possibility of independence from the interests of capital. The saying that a dog should not bite the hand that feeds it, neatly illustrates the problem with activity fuelled by monetary means. This increased possibility, however, requires further conditions to become a reality; notably, for instance, alternative economies allowing for the provision of food and shelter outside capital circulation/monetized relations; but an analysis of these conditions is beyond the remit of the present study. Nevertheless, it is important to note that the emancipatory character of demonetized relations is

\footnotetext{
12 'For Arendt, the economy loses against humanity. In On Revolution, Arendt (1963) dismisses the material base of poverty as a reason for a revolt in favour of freedom. Her philosophy is highly influenced by Ancient Greek thinkers who have also belittled the economy in favour of greater ideals. Consequently, the categories of paid and unpaid work are controversial in relation to Arendt.'
} 
not guaranteed. That is, while demonetization may be necessary, it is not considered to be a sufficient condition for effective action for degrowth.

Even if Arendt's tripartite differentiation may seem too rigid, it reminds everybody that the best (labour and work) practices lose all (or most of) their political value, whenever they persist in being isolated initiatives that are not communicated to and discussed with the other members of the political community. Accordingly, at the international degrowth conferences that have taken place to date, organizers and participants have tried to find the best synergy between righteous productive activeness and political analysis, confrontation, and discussion. Perhaps that is why for the degrowth movement, and particularly for imagining the required practices for degrowth, Arendt's theory of action and her revival of the ancient notion of praxis are central contributions. Building on Arendt's vision of political change, the current article suggests that activities of degrowth could aim to increase the role of political activity. However, in the current economic system geared to growth, to augment the effects of political action is to act outside the monetary frame. Accordingly, there is a need for not only more political action, but for more non-paid political action. The ability to take such action, must be supported by non-paid labour and work to meet the vital needs of active humans, such as food and shelter. Real life examples of these non-paid alternatives include ecovillages and local communities that use barter and time banks as means to replace the monetary, interest and debt-based transactions. Related literature again includes, for example, the works of André Gorz, who examined this issue in his La Misère du Présent (1997) and Immatériel (2003) containing his reflections on local exchange systems and other localization movements. Similarly, American economist Juliet Schor also discusses the emergence of diverse non-monetized or small-scale economic activities in her True Wealth (2010) [see also Perkins' (2010) critique of degrowth, which clarifies the limitations of non-paid activities from the perspective of gender justice]. 


\section{Conclusion}

The contribution of Arendt to degrowth is clearly manifold and this article was only able to scratch the surface of this broad field of study. To begin imagining her contribution, this study analysed the Arendtian conceptualization mainly through her writings on action included in The Human Condition but also in other volumes. Arendt problematizes labour and work as depoliticized activity supporting the totalitarian organization of societies, and moreover calls for a rebirth in the form of political activity as the solution. The main relevance to the degrowth movement of her work on action can be considered the insightful distinction between different forms of activity. The current research drew on Arendt's work to propose three implications for the degrowth movement. First, more political action is needed, as work and labour take time and energy away from fomenting desired change. Second, in the spirit of pluralism, the degrowth movement should not seek to outline a single, most effective degrowth activity but facilitate an inclusive dialogue on activities of and for degrowth. Third, activists and scholars are encouraged to explore ways to refrain from the growth economy by demonetizing activities of labour, work, and action.

For political change, action, as defined by Arendt, could certainly be utilized as a foundation for the degrowth movement. Its unpredictability could provide meaning to the somewhat rigid ecological economics and social sciences related discourse and action arising from the degrowth movement. However, applying a degrowth lens to the Arendtian theory of action, all forms of human activity can also be problematized due to their tendency to increase matter/energy throughput. All human labour and work are contributing to an already too extensive human-made world, where natural environments are limited, if not already extinct and absent (McKibben, 1989). Even political action, in the Arendtian sense, requires some matter/energy inputs, but arguably plays a minor role compared to the ecological damage 
caused by labour (e.g. broad scale industrial farming) and work (e.g. modern building construction).

The current article accords with Arendt's insight that the origin of most contemporary problems is the disappearance of action, but argues from the degrowth perspective for the need to complement the analysis with a distinction between paid and non-paid activity. While following Arendt in emphasizing the utmost importance of political engagement, the article also underscores the importance of non-paid labour through physical activity such as community supported agriculture, and non-paid work through social activity such as building off-grid energy systems for degrowth. It is proposed that non-paid activity, particularly in the form of political action, has great potential to contribute to degrowth, because monetary transactions in an interest and debt-based capitalist society tend to contribute to economic growth that is deemed ecologically unsustainable.

\section{Acknowledgements}

The authors are grateful to the editors of the journal as well as to the four anonymous reviewers for their helpful comments on the manuscript. Pasi Heikkurinen's part of this project has received funding from the European Union's Horizon 2020 research and innovation programme under the Marie Sklodowska-Curie grant agreement No 707652.

\section{References}

Alcott, B. 2005. Jevons' paradox. Ecological Economics, 54(1), 9-21. Arendt, H. (1951) 1985. The Origins of Totalitarianism. New York: Schocken Books. 
Arendt, H. (1954) 1961. Between Past and Future: Six Exercises of Political Thought. London: Faber and Faber.

Arendt, H. (1958) 1998. The Human Condition. Chicago - London: University of Chicago Press.

Arendt, H. (1963) 1990. On Revolution. London: Penguin Books.

Arendt, H. (1963) 2006. Eichmann in Jerusalem: A Report on the Banality of Evil. New York: Penguin Books.

Arendt, H. (1968) 1983. Men in dark times. San Diego - New York - London: Harcourt Brace \& Company.

Arendt, H. 1978. The Life of the Mind. New York - London: Harcourt.

Arendt, H. and Jaspers, K. (1985) 1993. Correspondence 1926-1969, edited by Kohler, L. and Saner, H. Harcourt and Brace, Florida.

Asara, V., Otero, I., Demaria, F., Corbera, E. 2015. Socially sustainable degrowth as a social-ecological transformation: Repoliticizing sustainability. Sustainability Science, 10(3), 375-384.

Bataille, G. (1967) 1988. The Accursed Share: An Essay on General Economy. New York: Zone Books.

Beck, U. (1986) 1992. Risk Society: Towards a New Modernity. New Delhi: Sage.

Benhabib, S. 2007. Situating the Self. Cambridge : Polity Press.

Boltanski, L. and Chiapello, E. (1999) 2005. The New Spirit of Capitalism. London - New York: Verso.

Bonnedahl, K. J., Heikkurinen, P. 2018. Strongly Sustainable Societies: Organising Human Activities on a Hot and Full Earth. Routledge: London and New York.

Bookchin, M. 1980. Toward an Ecological Society. Montreal: Black Rose Books.

Bookchin, M. 1982. The Ecology of Freedom: The Emergence and Dissolution of Hierarchy. Montreal: Black Rose Books.

Boulding, K. E., 1966. The Economics of the Coming Spaceship Earth, in H. Jarrett (Ed.). Environmental Quality in a Growing Economy, Johns Hopkins University Press, London, pp. 3-14. 
Canovan, M. (1992) 1994. Hannah Arendt A Reinterpretation of her Political Thought, Cambridge University Press, New York.

Castoriadis, C. (1975) 1988. The Imaginary Institution of Society. Cambridge MA - London: The MIT Press.

Castoriadis, C. 2005. Une Société à la derive. Paris: Seuil.

Cattaneo, C., D’Alisa, G., Kallis, G., Zografos, C. 2012. Degrowth futures and democracy. Futures 44(6), 515-523.

Crutzen P. J., Stoermer, E. F. 2000. The Anthropocene. Global Change Newsletter 41: 17-18.

D’Alisa, G., Demaria, F., Kallis, G. (Eds.), 2014. Degrowth: A vocabulary for a new era. Oxon: Routledge.

Daly, H. E. 1973. Toward a steady-state economy. San Francisco, USA: W.H. Freeman.

Daly, H. E. 1996. Beyond growth. Boston: Beacon Press.

Demaria, F., Schneider, F., Sekulova, F., Martínez-Alier, J., 2013. What is degrowth? From an activist slogan to a social movement. Environmental Values 22(2), 191-215.

Dietz, R. and O'Neill, D. W. 2013. Enough is enough: Building a sustainable economy in a world of finite resources. Oxon: Routledge.

Eskelinen, T., Wilén, K. 2018. Rethinking economic ontologies: From scarcity and market subjects to strong sustainability. In Bonnedahl, K. J. \& Heikkurinen, P. (eds.) Strongly Sustainable Societies: Organising Human Activities on a Hot and Full Earth. Routledge: London and New York.

Exner, A. 2014. Degrowth and demonetization: on the limits of a noncapitalist market economy. Capitalism Nature Socialism, 25(3), 9-27.

Foster, J. B. 2011. Capitalism and degrowth: An impossibility theorem. Monthly Review 62(8), 26-33.

Foster, J. B. 2015. Marxism and Ecology. Monthly Review, 67(7), 1.

Fournier, V. 2008. Escaping from the economy: the politics of degrowth. International Journal of Sociology and Social Policy, 28(11/12), 528545. 
Georgescu-Roegen, N. 1975. Energy and economic myths. Southern Economic Journal 41, 347-381.

Gorz, A. (1988) 1989. Critique of the Economic Reason. London: Verso.

Gorz, A. (1991) 1994. Capitalism, Socialism, Ecology. London: Verso.

Heikkurinen, P. (2016). Degrowth by means of technology? A treatise for an ethos of releasement. Journal of Cleaner Production. Doi: 10.1016/j.jclepro.2016.07.070.

Illich, I. (1973) 1990. Tools for Conviviality. London: Boyars.

Illich, I. 1978. The Right to Useful Unemployment and Its Professional Enemies. London: Boyars.

IPCC (Intergovernmental Panel on Climate Change), 2014. Fifth Assessment Report. Climate change 2014: Impacts, Adaption, and Vulnerability. Working Group II. Geneva: Intergovernmental Panel on Climate Change. Available at: http://www.ipcc.ch/report/ar5/.

Kallis, G., Demaria, F., D’Alisa, G. 2014. Introduction: degrowth, in: D’Alisa, G., Demaria, F., Kallis, G., (Eds.), Degrowth: a vocabulary for a new era. London: Routledge, pp. 1-17.

Kallis, G., Kerschner, C., Martínez-Alier, J. 2012. The economics of degrowth. Ecological Economics 84, 172-180.

Kallis, G., Kostakis, V., Lange, S., Muraca, B., Paulson, S., \& Schmelzer, M. 2018. Research on Degrowth. Annual Review of Environment and Resources. Doi: 10.1146/annurev-environ-102017-025941.

Kristeva, J. 2001. Hannah Arendt. New York: Columbia University Press.

Latouche, S. (2007) 2009. Farewell to Growth. Cambridge: Polity Press.

Levin, M. (1979). On animal laborans and homo politicus in Hannah Arendt: A note. Political theory, 7(4), 521-531.

Lorek, S., Fuchs, D. (2013). Strong sustainable consumption governanceprecondition for a degrowth path? Journal of Cleaner Production, 38, $36-43$.

Martínez-Alier, J., Pascual, U., Vivien, F.D., Zaccai, E., 2010. Sustainable degrowth: Mapping the context, criticisms and future prospects of an emergent paradigm. Ecological Economics 69(9), 1741-1747. 
Marx, K. (1844) 1959. Economic and Philosophic Manuscripts of 1844. Moscow: Progress Publishers.

Marx, K., Engels, F. (1932) 1968. The German Ideology. Moscow: Progress Publishers.

Mauss, M. (1950) 2002. The Gift: The Form and Sense of Exchange in Archaic Societies. London - New York: Routledge.

McKibben, B. 1989. The End of Nature. New York: Anchor.

Meadows, D. H., Meadows, D. I., Randers, J. and Behrens, W. 1972. The Limits to Growth. New York: New American Library.

Meadows, D. H., Randers, J. and Meadows, D. I. 2004. Limits to Growth: The 30-Year Update. White River Junction, VT: Chelsea Green.

Nelson, A. 2016. Non-Monetary Degrowth is Strategically Significant. Paper presented at the 5th International Degrowth Conference in Budapest, Hungary, 30.8.-3.9.2016.

Nelson, A. 2001. The poverty of money: Marxian insights for ecological economists. Ecological Economics, 36(3), 499-511.

Perkins, P. E. (2010). Equitable, ecological degrowth: Feminist contributions. Presented at the 2nd International Conference on Economic Degrowth for Ecological Sustainability and Social Equity, March.

Ruuska, T. 2017. Capitalism and the absolute contradiction in the Anthropocene. In: Heikkurinen, P. (ed) Sustainability and Peaceful Coexistence for the Anthropocene. New York and London: Routledge.

Scott, J. C. 1998. Seeing like a state: How certain schemes to improve the human condition have failed. Yale University Press: Yale.

Sekulova, F., Kallis, G., Rodríguez-Labajos, B. and Schneider, F. 2013. Degrowth: from theory to practice. Journal of Cleaner Production, 38, $1-6$.

Steffen, W., Richardson, K., Rockström, J., Cornell, S. E., Fetzer, I., Bennett, E. M., ... \& Folke, C. (2015). Planetary boundaries: Guiding human development on a changing planet. Science, 347(6223), 1259855. 
Swyngedouw, E. 2015. Depoliticization ('the political'). In G. DAlisa, F. Demaria, \& G. Kallis (Eds.), Degrowth: A vocabulary for a new era (pp. 90-93). Routledge: Oxon and New York.

Turner, G. M. (2008). A comparison of The Limits to Growth with 30 years of reality. Global Environmental Change, 18(3), 397-411.

UNEP (United Nations Environment Programme), 2011. Decoupling Natural Resource Use and Environmental Impacts from Economic Growth. A Report of the Working Group on Decoupling to the International Resource Panel. English summary. Available at http://www.unep.org/resourcepanel/Portals/24102/ PDFs/DecouplingENGSummary.pdf.

Zoellick, J. C., Bisht, A. 2017. It's not (all) about efficiency: Powering and organizing technology from a degrowth perspective. Journal of Cleaner Production. Doi: https://doi.org/10.1016/j.jclepro.2017.03.234. 